\title{
IMPACT OF CLINICAL MASTITIS IN DAIRY FARMING AT KESHABPUR UPAZILLA IN JESSORE IN BANGLADESH
}

\author{
S. Hossain*, M. A. Reza, M. N. Hasan, M. G. Sorwar and M. Billah \\ Department of Medicine, Surgery and Obstetrics, Faculty of Animal Science and Veterinary Medicine, \\ Patuakhali Science and Technology University, Dumki-8602, Patuakhali, Bangladesh.
}

\begin{abstract}
The study was conducted at upazilla veterinary hospital, Keshabpur, Jessore during the period of March 2013 to August 2013 to estimate the impact of clinical mastitis in dairy cows. Clinical mastitis was diagnosed on the basis of clinical signs and strip cup test (SCT). A total of 432 cases of dairy animals were recorded among them 65 cases were mastitis. The overall prevalence of mastitis was $15.05 \%$. The prevalence of mastitis was $12.04 \%$ and $3.01 \%$ in cows and does respectively. In doe, the prevalence was $7.14 \%$ in Jamunapari goat and $4.46 \%$ in Black Bengal goat. Reproductive stages enhanced the prevalence of mastitis. The prevalence of mastitis was also significantly affected by floor conditions where $10.42 \%$ in cows and $8.04 \%$ in does in the farms with brick-block floor and $6.51 \%$ in cows and $3.57 \%$ in does with soil floor. The efficacy of Ceftriaxone and amoxicillin was better than gentamicin and streptomycin. Hygienic condition showed lower prevalence of mastitis $1.63 \%$ and $1.79 \%$ in cow and does respectively than the unhygienic farm.
\end{abstract}

Keywords: Clinical mastitis, SCT, cross breed, breed

INTRODUCTION

The term "Mastitis" is derived from Greek word "matos" which means "breast" (mammary gland) and "itis" means Inflammation. Mastitis is the inflammation of the parenchyma of the mammary gland regardless of cause. It is characterized by a range of physical and chemical changes in the milk, and pathological changes in the glandular tissue (Atakan, 2008). The most important changes in the milk include discoloration, the presence of clots and the presence of large number of leukocytes (Hameed et al., 2012). There is swelling, heat, pain and in duration in the mammary gland in many clinical cases. However, a large proportion of mastitic glands are not readily detectable by manual palpation or by visual examination of the milk using a strip cup (Mbilu, 2007). Mastitis is one of the most devastating diseases in the dairy industry. Economic consequences of mastitis, clinical or sub-clinical, include reduced milk yield, poorer quality milk, increased culling rate and increased cost of veterinary services and medicine. Dairy farmers in Bangladesh are not always aware of the best practices to control mastitis (Rahman et al., 2009).

Economic loss to mastitis in the United States is estimated to be approximately (\$185)/cow annually. If we assume the same milk price and this value is multiplied by the total number of milking cows (9.5 million)/ head, the total annual cost of mastitis is about (\$1.8) billion. This is approximately $10 \%$ of the total value of farm milk sales, and about two-thirds of this loss is due to reduced milk production in sub clinically infected cows (Sargeant et al., 2001).The average production loss per lactation for one infected quarter is about 1600 pounds. Other losses are due to discarded abnormal milk and milk withheld from cows treated with antibiotic, costs of early replacement of affected cows, reduced sale value of culled cows, costs of drugs and veterinary services, and increased labor costs (NMC, 1999). The primary cause of mastitis in cattle, goats and sheep are well-recognized groups of microorganisms such as Streptococcus sp., Staphylococcus sp., Pasteurella sp. and Escherichia coli, Enterobacter sp. and Klebsiella sp. Recent studies at the University of Missouri collected data on the incidence of subclinical mastitis in ewes and identified Staphylococcus sp. Streptococcus $s p$ and Micrococcus sp found in bacterial cultures (Lalrintluanga et al., 2003; Rahman et al., 2010). The source of infection is contagious pathogens, environmental pathogens and other pathogens (Khan and Muhammad, 2005). Mastitis is caused by many different infectious agents commonly divided into Contagious pathogens (Streptococcus agalactiae, Staphylococcus aureus, Mycoplasma bovis) causing contagious mastitis and Environmental pathogens (Streptococcus uberis, Streptococcus dysgalactiae are most prevalent and Gram negative bacteria Escherichia coli, Klebsiella sp., Citrobacter sp., Enterobacter sp. etc.) causing environmental mastitis (Radostits et al., 2000).

*Corresponding e-mail address: daltonvetbd07@ gmail.com

Copyright (C) 2016 Bangladesh Society for Veterinary Medicine

All rights reserved 0353/2016 


\section{S. Hossain and others}

These are major pathogens. Some minor pathogens also causing mastitis including coagulase negative Staphylococcus spp. such as Staphylococcus hyicus and Staphylococcus chromogenes (Islam et al., 2011b).

Although mastitis was known to occur markedly in dairy cows, it appears recently that the frequency has dramatically increased in small holder dairy farms. These were the points which initiated the study to be done on the topic of mastitis. Therefore, the main objective of this study was to know the prevalence of mastitis in relation to species, farm type, breed and hygienic condition. Also observe the effects of drugs (antibiotics) in response to mastitis in different species. This study justifies the economic impact of mastitis including how it varies in different settings and which measure should be done for the control or reduce the disease occurrence of mastitis.

\section{MATERIALS AND METHODS}

The study was conducted at upazilla veterinary hospital, Keshabpur, Jessore during the period of March 2013 to August 2013. A total of 432 cattle suffering with mammary gland disease were examined where 65 cases were mastitis. A case of clinical mastitis was diagnosed on the basis of clinical findings and strip cup test (SCT). Udders and milk were examined to identify clinical mastitis. Clinical findings observed inflammatory udder redness, heat, swelling and pain. The milk could vary from having a few milk clots (garget) to serum with clumps of fibrin in the secretion, The mammary gland was edematous or very hard on palpation and The milk looked watery serous or purulent. Mainly mastitis was diagnosed based on clinical signs. But for the Strip cup test, Milk samples were collected aseptically from individual affected quarter of udder. Before taking samples the history of the milch animal and clinical signs was recorded through questionnaire.

\section{Strip cup test (SCT)}

The strip cup consists of a flat enamel plate partitioned into an area. The plate is black in color so that clot is clearly visible. Besides enamel plate this test can be done in a bowel covering a black cloth. At first udder was cleaned and wiped with clean cloth soaked in disinfectant $\rightarrow$ then udder was allowed to dry $\rightarrow$ milk was collected directly in sterile tube and labeled and then poured on black cloth above the enamel plate $\rightarrow$ then observed the clots or flakes.

\section{Statistical analysis}

Data were analyzed by Chi-square test to observe the significant influence of different prevalence, breed, quarters of udder, reproductive state, peri parturient disease, floor components, hygienic condition, treatment and breeds was determined by chi-square test using SPSS-11.5 computer package program.

\section{RESULTS AND DISCUSSION}

A total of 432 dairy animals were brought to upazilla veterinary hospital, Keshabpur, Jessore during the period of 6 months. Among them 52 cows and 13 does had been diagnosed as mastitis. The prevalence of mastitis is $12.04 \%$ in cows and $3.01 \%$ in does (Table 1).

Table 1. Prevalence of mastitis in different animals

\begin{tabular}{llllc}
\hline Species & Total No of cases & Mastitis & Percentage (\%) & Chi-square test (P-value) \\
\hline Cows & 307 & 52 & 12.04 & $0.000^{* *}$ \\
Does & 112 & 13 & 3.01 & \\
Ewes & 13 & - & - & \\
\hline
\end{tabular}

** Significant at $\mathrm{p}<0.01$

Goswami et al. (2003) reported that $13.33 \%$ prevalence of clinical mastitis in dairy cows but in this study this is lower (12.03\%). Islam et al. (2011) found $19.9 \%$ mastitis in dry season. This finding is also vary with the observation of Dwivedi et al. (2004) who reported $16.72 \%$ prevalence of clinical mastitis in dairy cows at Pakistan. It is due to the population size, rearing system and breed of the species. 
The prevalence of mastitis in compared with other diseases was presented in the Table 2 where $15.05 \%$ of lactating animals were affected in mastitis in compared with other disease $84.95 \%$.

Table 2. Prevalence of mastitis in compared to other diseases

\begin{tabular}{llc}
\hline Diseases & No of cases $(\%)$ & Chi-square test (P-value) \\
\hline Mastitis & $65(15.05)$ & $0.000^{* *}$ \\
$\begin{array}{l}\text { Other diseases } \\
\text { (Milk Fever, Ketosis, Parasitic infestation etc.) }\end{array}$ & $367(84.95)$ & \\
\hline
\end{tabular}

** Significant at $\mathrm{p}<0.01$

Table 3. Prevalence of mastitis in case of breeds of cow and goats

\begin{tabular}{lllc}
\hline Types of breeds & No of cows & Prevalence $(\%)$ & Chi-square test (P-value) \\
\hline Cross & 39 & 12.7 & $0.000^{* *}$ \\
Local & 13 & 4.23 & $0.000^{* *}$ \\
Jamunapari & 08 & 7.14 & \\
Local(BBG) & 05 & 4.46 & \\
\hline
\end{tabular}

** Significant at $\mathrm{p}<0.01$

The results in the Table 3 were similar to the observations made by Barbosa et al. (2002) who recorded higher frequency of mastitis in cross breeds. The findings of other researchers indicated that high yielding cows are more prone to udder infection than low producing one (DaSilva et al., 2004; Radostits et al., 2000). Because the production of large quantity of milk keep the glandular tissue more generative and thus become more susceptible to infections. Cross breed cows produce more milk than the local zebus. Bigger size, long and pendulous udder in cross breed cow might have picked up more infection resulting higher rate of infection (Patel et al., 2000). But the result due to improper hygienic condition and ignorance of the farmer.

Table 4. Number of quarters affected in mastitis

\begin{tabular}{llll}
\hline Quarter affected & No of cows $(\%)$ & No of does $(\%)$ & Chi-square test (P-value) \\
\hline One quarter & $28(9.12)$ & $08(7.14)$ & $0.000^{* *}$ \\
More than one & $24(7.81)$ & $05(4.46)$ & \\
\hline
\end{tabular}

** Significant at $\mathrm{p}<0.01$

It has been shown that one quarter is more $9.12 \%$ affected than two or more number $7.81 \%$ of quarters in cows and $7.14 \%$ and $4.46 \%$ in does respectively (Table 4). Because in most cases mastitis starts with one teat infection, then it gradually spread to other teats (quarters). When treatment is performed the probability of infection to other teat is reduced. About $9.12 \%$ cows and $7.14 \%$ does were affected with one teat infection and $7.81 \%$ cows and $4.46 \%$ does affected with more than one quarters. The statement is quietly supported by Rainard and Riollet (2006) and Samad (2008) who reported that about 34\% cows affected with one quarter affected. In both species the percentage of mastitis were higher in non-pregnant and lactating cows $14.98 \%$ and $100 \%$ in does and lactating animal that pregnant and lactating cows $1.95 \%$ and $0 \%$ in does (Table 5).

Table 5. Prevalence of mastitis on reproductive state

\begin{tabular}{llll}
\hline Reproductive state & No of cows $(\%)$ & No of does $(\%)$ & Chi-square test (P-value) \\
\hline $\begin{array}{l}\text { Pregnant and } \\
\text { Lactating }\end{array}$ & $6(1.95)$ & - & $0.000^{* *}$ \\
Non pregnant and lactating & $46(14.98)$ & $13(100)$ & \\
\hline
\end{tabular}

** Significant at $\mathrm{p}<0.01$ 


\section{S. Hossain and others}

In pregnant and lactating animal the amount of milk production is reduced due to lower amount of prolactin release and lower nutritional level because fetus takes a great part on nutrition. Moreover, low milk production is less prone to mastitis (Kader et al., 2002; Sederevicius et al., 2006) which is similar with this study. A total of 50 cows were affected with periparturient diseases. Cows without a history of periparturient disease had prevalence of $0.65 \%$ mastitis; in contrast, $16.28 \%$ of cows with a history of periparturient disease had mastitis (Table 6).

Table 6. Percentages of mastitis in cows with peri parturient diseases

\begin{tabular}{lll}
\hline Condition & Affected animals (\%) & Chi-square test (P-value) \\
\hline $\begin{array}{l}\text { Cows without a history of } \\
\text { periparturient disease }\end{array}$ & $2(0.65)$ & $0.000^{* *}$ \\
Cows with a history of periparturient disease & $50(16.28)$ & \\
\hline
\end{tabular}

** Significant at $\mathrm{p}<0.01$

The result is supported with (Seegers et al., 2003). The lower immunity level of periparturient cows makes the cow more prone to infection in the udder (Rainard and Riollet, 2006). Once a cow gets infected or diseased during the periparturient period, it becomes more susceptible to udder infection due to lowered immunity (Sarker and Samad, 2011; Sharma et al., 2007). Calcium ions are necessary for muscle constriction. As a result, in milk fever, low level of calcium decreases the rigidity of the teat sphincter that perhaps allows the organism to pass into the udder. In addition, cows having infected uterine discharge and retained placenta risk the udder and teats being contaminated (Zaki et al., 2008).

Table 7. Mastitis of cow depending on floor component

\begin{tabular}{llll}
\hline Floor condition & Total cases: cows $(\%)$ & Total cases: does $(\%)$ & Chi-square test (P-value) \\
\hline Brick block floor & $32(10.42)$ & $9(8.04)$ & \\
Soiled floor & $20(6.51)$ & $4(3.57)$ & $0.000^{* *}$ \\
\hline
\end{tabular}

** Significant at $\mathrm{p}<0.01$

Prevalence of mastitis depending on floor condition was $10.42 \%$ in cows and $8.04 \%$ in does in farms with brick-block floor and $6.51 \%$ in cows and $3.57 \%$ in does in farms with soil floor (Table 7). The prevalence of mastitis was also significantly affected by floor conditions (completely dry vs. partly or completely wet and soiled floor). This can be explained by the fact that farms with soil floor would dry more quickly than the brick floor (Sharma et al., 2008). As a result soiled floor animal were less affected than brick block floor. But wet soiled floor (less absorbable) are most harmful for dairy animal to cause mastitis. It appeared that the floor was a potential source for mastitis organisms to enter the udder through the teat orifice (Wakwoya et al., 2006).

Table 8. Mastitis in relation to hygienic condition of farm

\begin{tabular}{llll}
\hline Category & Total cases: cows $(\%)$ & Total cases: does $(\%)$ & Chi-square test $(\mathrm{P}$-value $)$ \\
\hline Hygienic & $5(1.63)$ & $2(1.79)$ & \\
Unhygienic & $47(15.3)$ & $11(9.82)$ & $0.000 * *$ \\
$* *$ Significant at $\mathrm{p}<0.01$ & &
\end{tabular}

Hygienic condition showed lower prevalence of mastitis $1.63 \%, 1.79 \%$ in cow \& does respectively than the unhygienic farm (Table 8). This result of present study is supported with the findings of Sharma et al.(2010) who reported that the prevalence of mastitis were found to be highest in cows managed with lower drainage system.

It is indicated that 35 infected cows were treated with gentamicin (Table 9). Among them 30 (85.71\%) cows were cured out of 35 . A total of 10 infected cows and 5 not cured cows treated with ceftriaxone and finally all cows were cured. A total of 2 infected cows were treated with amoxicillin and all were cured (100\%). A total of 
Impact of clinical mastitis in dairy farming

5 cows treated with Streptomycin-Penicillin and all were cured (100\%). Teat siphon (during block) and intramammary infusion was also used.

Table 9. Response to treatment in mastitis in case of cow

\begin{tabular}{lllll}
\hline Antibiotics & No of animals & Cured $(\%)$ & Not cure $(\%)$ & Chi-square test (P-value) \\
\hline Gentamicin & 35 & $30(85.71)$ & $5(14.29)$ & $0.000^{* *}$ \\
Ceftriaxone & $10+5$ (not cured) & $15(100)$ & - & \\
Amoxicillin & 2 & $2(100)$ & 0 & \\
Streptomycin and & 5 & $5(100)$ & - & \\
Penicillin & & & \\
\hline
\end{tabular}

** Significant at $\mathrm{p}<0.01$

The statement was supported with Tanwar et al. (2001) who identified that Staphylococcus spp were the most commonly found pathogen. These isolates were sensitive to Gentamicin and Ceftriaxone. Sudhan et al. (2005) also stated that Neomycin, Chloramphenicol and nitrofurantoin were found to be most effective against mastitis pathogens. In addition with, pain killer (Diclofenac sodium or Ketoprofen) or sometimes Steroid (Dexamethason) and antihistaminic (Chlorphenaramine maleate) were used.

\section{CONCLUSION}

The study also showed that higher prevalence of clinical mastitis in large, lower, medium and backyard farm is due to management system as well as proper knowledge of dairy farming. A well documented continued research and educational effort is required to increase producer awareness to reduce mastitis in dairy enterprise.

\section{ACKNOWLEDGEMENTS}

The authors are grateful to Dr. Sawpan Kumar Roy, upazilla veterinary hospital, Keshabpur, Jessore for his kind help and cooperation in this study.

\section{REFERENCES}

1. Atakan KOC (2008). A study of somatic cell counts in the milk of Holstein-Friesian cows managed Mediterranean climatic condition. Turkish Journal of Veterinary and Animal Sciences 32: 13-18.

2. Barbosa CB, Benadetti E, Ribeiro SC, Guimares EC and Ribeiro SC (2002). The relationship between somatic cell count (SCC) and result of the California Mastitis Test (CMT) to diagnose bovine mastitis. Bioscience Journal 18: 93-102.

3. DaSilva ER, Siqueira AM, Martins JCD, Ferreira WPB and DaSilva N (2004). Identification and in vitro antimicrobial susceptibility of Staphylococcus species isolated from goat mastitis in the Northeast of Brazil. Small Ruminant Research 55: 45-49.

4. Dwivedi HP, Kumar M and Upadhyay AK (2004). Biochemical changes in cows suffering from mastitis. Indian Journal of Veterinary Medicine 24: 101-102.

5. Goswami SN, Roy A and Kalyani IH (2003). A comparative study on various indirect tests to direct isolation for detection of subclinical mastitis (SCM). In: proceeding of XXI Indian Society for Veterinary (ISVM) Conference, Anand, India. pp. 101-102.

6. Hameed S, Arshad M, Ashraf M, Avais M and Shahid MA (2012). Cross-sectional epidemiological studies on mastitis in cattle and buffaloes of tehsil burewala. The Journal of Animal and Plant Sciences 22: 371-376.

7. Islam MA, Islam MZ, Islam MA, Rahman MS and Islam MT (2011). Prevalence of subclinical mastitis in dairy cows in selected areas of Bangladesh. Bangladesh Journal of Veterinary Medicine 9: 73-78.

8. Islam MA, Samad MA and Rahman AKMA (2011). Bacterial pathogens and risk factors associated with mastitis in black Bengal goats in Bangladesh. Bangladesh Journal of Veterinary Medicine 9: 155-159.

9. Kader MA, Samad MA, Saha S and Taleb MA (2002). Prevalence and etiology of sub-clinical mastitis with antibiotic sensitivity to isolated organisms among milch cows in Bangladesh. Indian Journal of Dairy Science 55: 218-223. 


\section{S. Hossain and others}

10. Khan AZ and Muhammad G (2005). Quarter-wise comparative prevalence of mastitis in buffaloes and cross-bred cows, Pakistan Veterinary Journal 25: 9-12.

11. Lalrintluanga C, Ralte EC and Hmarkunga (2003). Incidence of mastitis, bacteriology and antibiogram dairy cattle in Aizawl, Mizoram. Disease Investigation Laboratory, AH and Veterinary Department, Mizoram, India. Indian Veterinary Journal 80: 931-932.

12. Mbilu TJNK (2007). Status of mastitis in lactating goats at Sokoine University of Agriculture and neighboring smallholder farms in Morogoro Municipality, Tanzania. Livestock Research Rural Development 19: 1-8.

13. Patel PR, Paval SK, Rao N, Mandali GC and Jani RG (2000). Status of mastitis in Gujarat State. In: Proceedings Round Table Conference of the Indian Association for the Advancement of Veterinary Research (IAAVR) Mastitis, IVRI, Izatnagar, India, pp. 45-52.

14. Radostits OM, Gay CC, Blood DC and Hinchcliff KW (2000). Mastitis In: Veterinary Medicine, A Textbook of the Diseases of Cattle, Sheep, Pigs, Goats and Horses. 9 Edn. W B Saunders Co. Philadelphia, USA pp. 603-612.

15. Rahman MA, Bhuiyan MMU, Kamal MM and Shamsuddin M (2009). Prevalence and risk factors of mastitis in dairy cows. TheBangladesh Veterinarian 26: 54-60.

16. Rahman MM, Islam MR, Uddin MB and Aktaruzzaman M (2010). Prevalence of subclinical mastitis reared in Sylhet District of Bangladesh. International Journal of Biological Research 1: 23-28.

17. Rainard P and Riollet C (2006). Innate immunity of the bovine mammary gland. Veterinary Research 37: 369-400.

18. Samad MA (2008). Animal Husbandry and Veterinary Science. Volume 2, $1^{\text {st }}$ edn, LEP No. 11, BAU Campus, Mymensingh, Bangladesh.

19. Sargeant JM, Leslie KE, Shirley JE, Pulkrabek BJ and Lim GH (2001). Sensitivity and specificity of somatic count and California mastitis test for identifying intramammary infection in early lactation. Journal of Dairy Science 84: 2018-2024.

20. Sarker H and Samad MA (2011). Udder-halve-wise comparative prevalence of clinical and subclinical mastitis in lactating goats with their bacterial pathogens and antibiotic sensitivity patterns in Bangladesh. Bangladesh Journal of Veterinary Medicine 9: 137-143.

21. Sederevicius A, Balsyte J, Lukauskas K, Kazlauskaite and Biziulevicius GA (2006). An enzymatic cow immunitytargeted approach to reducing milk somatic cell count: A comparative field trial. Food and Agricultural Immunology 17: 1-7.

22. Seegers H, Fourichon C and Beaudeau F (2003). Production effects related to mastitis economics in dairy cattle herds. Veterinary Research 34: 475-491.

23. Sharma N, Maiti SK and Sharma KK (2007). Prevalence, etiology and antibiogram of microorganisms associated with subclinical mastitis in buffaloes in Drug, Chhattisgarh State (India). International Journal of Dairy Science 2: 145-151.

24. Sharma N, Maiti SK and Pandey V (2008). Sensitivity of indirect tests in the detection of subclinical mastitis in buffaloes. Veterinary Practitioner 9: 29-31.

25. Sharma N, Pandey V and Sudhan NA (2010). Comparison of some indirect screening tests for detection of subclinical mastitis in dairy cows. Bulgarian Journal of Veterinary Medicine 13: 98-103.

26. Sudhan NA, Singh R, Singh M and Soodan JS (2005). Studies on prevalence, etiology and diagnosis of subclinical mastitis among crossbred cows. Indian Journal of Animal Research 39: 127-130.

27. Tanwar RK, Vyas SK, Fakhruddin and Singh AP (2001). Comparative efficacy of various diagnostic tests in diagnosis of SCM in Rathi cows. In: Proceedings of Round Table Conference of the Indian Association for the Advancement of Veterinary Research (IAAVR) on Mastitis 161-163.

28. Wakwoya A, Molla B, Belihu K, Kleer J and Hildebrantdt G (2006). A cross-sectional study on the prevalence, antimicrobial susceptibility patterns and associated bacterial pathogens of goat mastitis. International Journal of Applied Research in Veterinary Medicine 4: 169-176.

29. Zaki MS, Sharaf NE, Mostafa SO, Fawzi OM and EIBattrawy N (2008). Effect of subclinical mastitis on some biochemical and clinic-pathological parameters in buffalo. American-Eurasian Journal of Agriculture and Environmental Science 3: 200-204. 